\title{
InhA Inhibitors as Potential Antitubercular Agents (A Review)
}

\author{
HINNA HAMID \\ Department of Chemistry, Faculty of Science, Jamia Hamdard, \\ Hamdard Nagar, New Delhi 110062, India. \\ ${ }^{*}$ Corresponding author E-mail: hhamid@ jamiahamdard.ac.in \\ http://dx.doi.org/10.13005/ojc/320106
}

(Received: December 25, 2015; Accepted: February 26, 2016)

\begin{abstract}
Infectious diseases pose a potential threat and are responsible for killing more people globally than any other single cause. For six decades, antibiotics have been a bulwark against bacterial infectious diseases. This bulwark is failing due to the appearance of resistant bacterial strains. The biosynthesis pathway of fatty acids in bacteria represents a validated target for antibacterial drug discovery, although it is still relatively unexplored. Bacterial FAS-II is essential for survival of bacterial cells, furthermore as it is distinct from FAS-I pathway in mammals, it constitutes a rational beginning point for the design of novel anti-infective drugs. Tuberculosis (TB) is a potentially serious infectious disease. Several strategies that have been adopted for the development of new therapeutic agents against the strains of tuberculosis which are drug resistant involve not only the design and synthesis of compounds against earlier known targets but also the identification and inhibition of novel drug targets. Isoniazid (INH), the first-line agent used for prevention and treatment of tuberculosis targets the enoyl reductase (InhA) enzyme in fatty acid biosynthesis pathway of the mycobacteria. KatG, is the enzyme which activates isoniazid and mutations in this enzyme lead to the majority of INHresistant clinical strains. Thus only those compounds will work against most of the INH resistant strains of mycobacteria which do not require activation of KatG for InhA inhibition.
\end{abstract}

Key words: InhA,antibacterial, FAS II, rational design, Fabl inhibitors, enoyl ACP reductase, FAS.

\section{INTRODUCTION}

Tuberculosis (TB) is a potentially serious infectious disease. It has been reported that one third population of the world is affected with Tuberculosis and 9.6 million people suffered from Tuberculosis in 2014. In 2014 almost 9,421 people suffered from Tuberculosis (a rate of 2.96 cases per 100,000 persons) in the United States ${ }^{1}$. Mycobacterium tuberculosis (MTB) is a leading killer in patients suffering from AIDS and because of the advent of multidrug-resistant strains of MTB (MDRTB)) existing control measures are severely hindered ${ }^{2-4}$. The spread of this major disease is being prevented through chemotherapy as no effective vaccine is available. Isoniazid (INH) is one 
of the most potent and widely accepted drugs for treating tuberculosis and constitutes the current front line treatment regimen. Its mechanism of action includes disrupting the integrity of the mycobacterial cell wall by impeding mycolic acid biosynthesis ${ }^{5}$. Mycobacterium.tuberculosis strains were found to develop resistance to it almost immediately following its clinical use and about $30 \%$ of the clinical isolates currently are INH resistant. The mechanism of its action remained unclear until 1994, although it was introduced in 1952. It was found out that a missense mutation of the inhA gene led to development of resistance to isoniazid ${ }^{6}$ and that inhA gene in the Mycobacterium tuberculosis coded for the Fabl protein $(\operatorname{Inh} A)^{7}$. Isoniazid requires a prior activation by the KatG catalase/peroxidase and thus acts as a pro-drug, which is the underlying cause for fast development of resistance to isoniazid ${ }^{5-10} . M$. tuberculosis strains which are catalase/peroxidasedeficient remain virulent ${ }^{11}$. Despite the fact that the mechanism of action of isoniazid is complicated it is evident that InhA, the enoyl reductase (ENR) in the type II biosynthesis pathway of fatty acids, is the target for isoniazid ${ }^{12-15}, 6,7,16$. InhA was validated as a drug target for isoniazid by Jacobs and co-workers by revealing that a mutation caused by change in temperature caused inactivation of InhA, which led to the same phenotypic response as administration of Isoniazid ${ }^{26}$. Inhibition of InhA is affected by formation of an adduct between $\mathrm{NAD}(\mathrm{H})$ and INH after activation by KatG ${ }^{10,17-21}$ and compounds that could inhibit InhA without the requirement of activation by KatG, have remarkable potential as novel drugs for fighting MDRTB $22,23,9,22,24,25$.

Having known that for isoniazid targets InhA, several approaches such as computational simulation $^{27,28}$, selective optimization of side activities (SOSA $)^{29}$ and de novo design ${ }^{30}$ have been utilized for rational design of novel inhibitors of InhA with sub-nanomolar potency ${ }^{31,32}$.

\section{Classes of Inhibitors}

Three different classes of known inhibitors of ENR are based on isoniazid, diazaborines, and triclosan, the antibacterial agents that have shown to inhibit ENR. Two approaches, i.e., synthesis of several novel INH based antimycobacterial compounds or INH-NAD adducts have been used to develop isoniazid based molecules having better anti-mycobacterial potency. The other scaffolds identified by high-throughput screening (HTS)<smiles>NCCNC(=O)Cc1ccccc1F</smiles><smiles>Cc1cnc(-n2cccc2)nc1</smiles>

(3)<smiles>Oc1ccc(-c2cnn(-c3cc(C(F)(F)F)ccn3)c2)c(O)c1</smiles><smiles>O=C(c1ccc2[nH]ccc2c1)N1CCN(C2c3ccccc3-c3ccccc32)CC1</smiles>

Fig. 1: (1H-indol-5-yl)methanones (1), 2-(2-fluorophenyl)acetamides (2) 2-(pyrazol-1-yl) Pyrimidines (3) Genz-8575; (4) Genz-10850; (5) triclosan 
and exhibiting potent inhibition of ENR include piperazine, pyrrolidine carboxamides, pyrazoles, imidazopiperidines, indoleformamidesarylamides and arylcarboxamides.

\section{Structural generalizations}

Although the known InhA inhibitor classes are structurally diverse, two generalizations arise. The inhibitors bind to the enzyme in almost every case in presence of the oxidized and/or reduced cofactor, though isoniazid and the diazaborines bind as covalent adducts of the cofactor. Also that the efficiency of inhibition is often related to ordering of the loop of the enzyme meant for substrate binding located in the vicinity of the active site ${ }^{33}$ when slow onset inhibitors interact with the enzyme. An initial rapid association of enzyme and inhibitor precedes the slow complex formation step. Slow onset enzyme inhibitors remain bound to their target enzymes even in case of low free drug concentration and thus have long residence times on the enzyme, prolonging their activity $^{34-36}$.

In this review an overview of the existing status of ongoing efforts to develop inhibitors for enoyl reductase (Fabl) involved in the catalysis of a critical step in the FAS II pathway has been provided.<smiles>O=C1NC(O)(I)c2ccncc21</smiles>

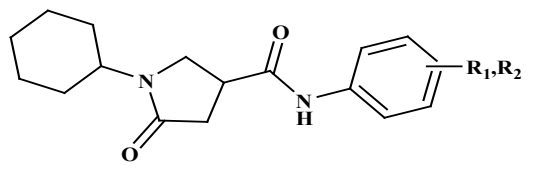<smiles>O=C(Nc1ccc(-c2ccccc2)c(O)c1-c1ccccc1)C1CC(=O)N(C2CCCCC2)C1</smiles>

Staveski et al., in (2001) reported synthesis of (1H-indol-5-yl) methanones (1), 2-(2-fluorophenyl) acetamides and 2-(pyrazol-1-yl) pyrimidines (3) as InhA inhibitors (2) $\left[\mathrm{R}^{2}=4-\mathrm{ClC}_{6} \mathrm{H}_{4} ; \mathrm{n}=2\right]$ which showed $82 \%$ InhA inhibition at $40 \mu \mathrm{M}^{37}$ (Fig. 1). Kuo et al., ${ }^{32}$ used high throughput screening to identify piperazine and pyrazole based inhibitors of InhA, the most effective compound (5) ((4- $(9 \mathrm{H}-$ fluoren-9-yl)piperazin-1-yl)(indolin-5-yl)methanone) was found to have an $\mathrm{IC}_{50}$ value for InhA of 0.16 $\mu \mathrm{M}$ and (4-(trifluoromethyl)-2-(4,5-dihydro-4-(2,4dinitrophenyl)pyrazol-1-yl)pyrimidine) (4) exhibited an $\mathrm{IC}_{50}$ of $2.4 \mu \mathrm{M}$, respectively. Although the piperazine-based compound was found to be less potent in vitro than the pyrazole derivative it repressed drug-resistant mycobacterium strains exhibiting an $\mathrm{MIC}_{99}$ value of $1-30 \mu \mathrm{M}$ (Fig. 1). A sequence of ortho-metallation -electrophilic substitution was reported to be used as a critical step by Broussy, S. et al.,(2005) $)^{38}$ for synthesis of 4-benzoylpyridine (7) scaffold. $N$-pyridyl alkylated analogues and 4-benzoyl pyridine-3-carboxamide derivatives which mimic the truncated Isoniazid-NAD adducts were present in a unique cyclized hemiamidal structure rather than the keto-amide open form. He et al., $(2006)^{39}$ used microarray parallel synthesis followed by high-throughput screening to report the discovery of various pyrrolidine carboxamides as a new class of inhibitors of ENR. On the basis of the preliminary SAR studies, a series of pyrrolidine carboxamide derivatives were synthesized through an amide forming reaction by modifying the pyrrolidine carboxamide framework, in situ screening of these compounds led to discovery of more effective inhibitors based on pyrrolidine carboxamide scaffold. Incidentally none of the compounds was found<smiles>[R16]c1ccc(NC2CCN(C(=O)c3cc[nH]c3)CC2)cc1</smiles><smiles>O=C(c1ccccc1)N1CCN(C2c3ccccc3-c3ccccc32)CC1</smiles>

Fig. 2: Pyrrolidine carboxamide and Aryl amide inhibitors 
to exhibit any activity against the malaria parasite Plasmodium falciparum (pfENR) or ecENR (enoyl reductase of $E$. coli). Rapid optimization of initial leads by structure-based iterative library approach led to development of inhibitors of InhA with nanomolar potency and compound (8) was found to be most active inhibitor exhibiting an $\mathrm{IC}_{50}$ of $140 \mathrm{nM}$. On evaluation of the pure enantiomers following the resolution of racemic mixtures it was found out that only one of the stereoisomers led to the inhibition showing an $\mathrm{IC}_{50}$ of $62 \mathrm{nM}$.

A new class of arylamide based direct inhibitors of InhA were discovered by Xin et al., (2007) using a high-throughput screening approach. These molecules were found to evade the mechanism of resistance to important antitubercular drugs like Isoniazid and ethionamide as they do not require any mycobacterial enzymatic activation. A series of compounds were synthesized by diversifying the amine group but retaining the piperazine scaffold using SAR studies (Fig.2). More potent InhA inhibitors were discovered by in situ screening using an expedient microtiter library synthesis. Compound (9) exhibiting an $\mathrm{IC}_{50}$ of $90 \mathrm{nM}^{40}$ was found to exhibit most potent inhibition.Unique structural features of Triclosan, the broad spectrum antibacterial compound, have been used for the development of more diphenyl ethers derivatives with better inhibition of enoyl reductase. Novel alkyl substituted diphenyl ether based InhA inhibitors have been developed by introducing various alkyl groups in place of chlorine atom on the phenol ring. A patent for diphenyl ether analogues as inhibitors of InhA has been claimed by Tonge et al., ${ }^{41}$. A library of alkyl substituted diphenyl ethers has been discovered to exhibit uncompetitive inhibiton of InhA. 8PP (10) the most potent compound, was reported to exhibit a $\mathrm{K}_{\mathrm{i}}^{\prime}$ value of $1 \mathrm{nM}$ against InhA and $\mathrm{MIC}_{99}$ values of 6-10 $\mathrm{mM}$ for both drugsensitive and drug-resistant strains of $\mathrm{MTB}^{31,42}$. In order to assess ${ }^{43}$ the potential of imidazopiperidines as inhibitors of FAS II for M. tuberculosis growth as lead compounds all the synthesized compounds were evaluated for inhibition of InhA using triclosan $\left(\mathrm{IC}_{50}=2.1 \mu \mathrm{M}\right)$, as the reference and the compounds exhibiting effective inhibition were further subjected to whole M. tuberculosis cell assay.

Preliminary observations showed that both $R^{1}$ and $R^{2}$ positions needed to be substituted for this scaffold to be active (11).

Compounds containing either the mono or dichloro benzyl substituent at the position $\mathrm{R}^{1}$ with $\mathrm{R}^{2}$ position having the electron donating paramethoxybenzylamine group $\left(12, I_{50}=0.24 \mu \mathrm{M}\right)$ were found to be the most active. Removal of one chloride group was found to lead to decrease in activity (13, $\left.\mathrm{IC}_{50}=0.41 \mu \mathrm{M}\right)$. SAR analysis of a group of hexyl substituted diaryl ethers with nitro-substituted phenyl ring or pyridine ring based InhA inhibitors reported by Ende et al., ${ }^{44}$ recommended that presence of a bulky group on the phenyl ring or phenyl ring with a nitrogen atom led to reduction of anti-InhA

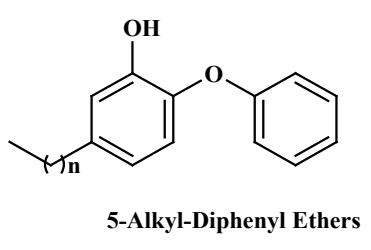

$8 \mathrm{PP}(\mathrm{n}=8)(10)$<smiles>COc1cc(OC)nc(Oc2ccc(C(C)(C)C)cc2O)n1</smiles>

(13)<smiles>[R12]C(=O)c1ccc(C2c3ncn([Z3])c3CCN2[Z1])cc1</smiles><smiles>CC(C)c1ccc(Oc2cnccn2)c(O)c1</smiles>

(14)<smiles>CC(C)(C)c1ccc(Oc2ccccc2)c(O)c1</smiles><smiles>COc1cc(OC)nc(Oc2ccc(C(C)(C)C)cc2O)n1</smiles>

(15) 
<smiles>COc1cc(O)cc(C(=O)Nc2ccc(C)cc2[N+](=O)[O-])c1</smiles><smiles>C/C=C/C</smiles><smiles>Cc1ccccc1Oc1ccc(C(C)(C)C)cc1O</smiles>

(24)

activity. 5-hexyl-2-phenoxyphenol (12) found to be a nanomolar inhibitor of InhA was also found to be effective against both sensitive as well as the isoniazid-resistant strains of M.tuberculosis showing an $\mathrm{MIC}_{90}$ of $1-2 \mu \mathrm{g} / \mathrm{mL}$. Although it displayed a
Compound $\mathbf{R}$

InhA IC50

(nM)<smiles>Oc1cc(I)ccc1Oc1ccc(Cl)cc1Cl</smiles>

Triclosan

$\begin{array}{lc}\mathrm{Cl} & 1100 \pm 180 \\ \mathrm{Me} & 800 \pm 99 \\ 2 \mathrm{H}- & >10000 \\ \text { tetrazol-5-yl } & \\ \mathrm{COOH} & >10000 \\ \mathrm{C}(\mathrm{O}) \mathrm{NH}_{2} & >10000 \\ \mathrm{Ph} & >10000 \\ \mathrm{CH}_{2} & 110 \pm 31 \\ \left(\mathrm{C}_{6} \mathrm{H}_{11}\right) & \end{array}$

significant in vitro activity, its ClogP value was over 5 and thus in order to reduce the lipophilicity and hence enhance the bioavailability, several $B$ ring derivatives of (12) with either nitrogen containig heterocyles or nitro, amino, amide or piperazine substituted phenyl rings were designed and synthesized. Compounds (13), (14) and (15) showed $\mathrm{MIC}_{90}$ comparable with (12) and better ClogP. LeapFrog program was used to carry out CoMFA analysis of pyrrolidine carboxamides which were reported as selective $m$ tInhA inhibitors followed by subsequent de novo

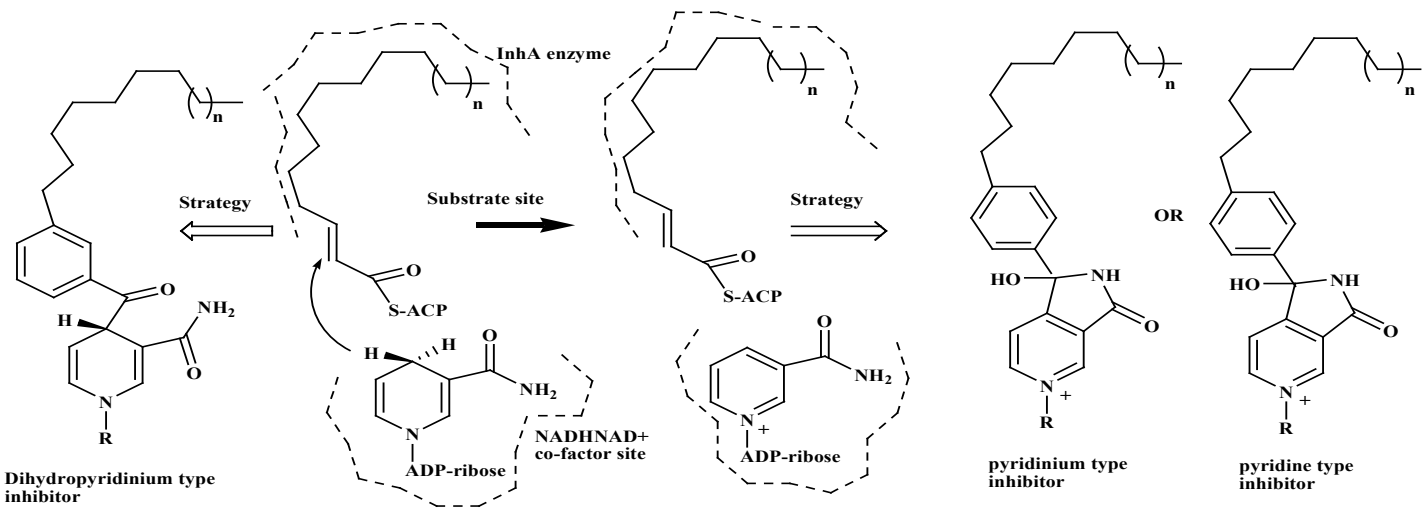<smiles>CCOc1cccc(C2(O)NC(=O)c3cnccc32)c1</smiles><smiles></smiles>

(26)<smiles>[Y]N1C=CC(C(=O)c2cccc(CC(C)(C)C)c2)C(C(N)=O)=C1</smiles>

(27)<smiles></smiles>

(28) $\mathrm{R}=\mathrm{CH}_{2} \mathrm{COOEt}$ (29) $\mathrm{R}=\mathrm{CH}_{2} \mathrm{COO}\left(\mathrm{CH}_{2}\right)_{3} \mathrm{OH}$

Fig. 3: pyridinium, pyridine, and 1,4-dihydropyridines as potent Mycobacterium Tuberculosis ENR inhibitors 
ligand design by Ashutosh et al., ${ }^{44}$. The designed pyrrolidine carboxamide derivatives showed better predicted activity in comparison to already reported molecules using the CoMFA model, suggesting that the proposed molecules could be more selective and effective against InhA. A tripeptide inhibitor with the sequence WYW was identified using a structure-based approach with the help of the crystal structure of Inh A with a known series of pyrrolidine carboxamides. It was found to have 100 fold more potency than the known inhibitors and could thus act as a useful lead molecule for further development of novel anti-TB compounds ${ }^{30}$. For discovering novel and direct InhA inhibitors in silico an effective approach was developed by Xiao-Yun Luet al., in 2009. A pharmacophore model was built employing bioactive conformation of pyrrolidine carboxamide inhibitor bound to InhA. This model was effectively applied to screen the SPECS database in order to identify the biologically active conformations of pyrrolidine carboxamide derivatives and align them; moreover a 3D-QSAR model which was statistically valid was also obtained. This led to selection and identification of 30 hit molecules as good leads from the database screening, which was followed by docking studies on molecules 16 and 17 to explore their interactions with ENR. Furthermore based on the generated pharmacophore model the interactions between known pyrazole based inhibitors and ENR were analyzed ${ }^{27}$. Using the approach of structure- based drug design several 5- substituted triclosan derivatives were synthesized in an attempt to develop diphenyl ethers with improved activity against InhA. Two groups of derivatives developed with enhanced potency against purified InhA had alkyl and aryl substituents. Most potent InhA inhibitor exhibiting $\mathrm{IC}_{50}$ of $21 \mathrm{nM}$ displayed 50 times better potency than triclosan. Structural attributes required for the inhibition were revealed by the study of four triclosan derivative bound $X$ - ray crystal structures of ENR. Among the six derivatives selected and tested the most potent inhibitor (23) exhibited ten times enhancement of the anti-bactericidal activity in comparison with triclosan and was found to display an MIC of $4.7 \mu \mathrm{g} \mathrm{mL}^{-1}(13 \mu \mathrm{M})$. A subset of these triclosan analogs were also reported to be more potent against two strains of $M$. tuberculosis resistant to isoniazid, pointing to the importance of such structure- based design strategies for development of efficient drugs against tuberculosis ${ }^{45}$.

In order to design slow onset diphenyl ethers, as inhibitors of ENR, it was reasoned that for loop ordering an entropic penalty must exist and thereby if conformational tractability of the lead compound is restricted it could lead to ordering of the loop in the active site resulting in slow binding interaction or slow onset inhibition of the target enzyme. Insertion of a methyl group at ortho position to the diphenyl ether linkage led to the formation of PT70 (24), which was found to cause slow onset inhibition of ENR exhibiting a $\mathrm{K}_{\mathrm{i}}$ of $22 \mathrm{pM}$. Analysis of the X-ray crystallographic structure of PT70 with ENR verified the fact that ordering of the loop for substrate-binding led to slow onset inhibition of the enzyme. The presence of the methyl group on B-ring of PT70 was found to exhibit crucial van der Waal's<smiles>CCOc1ccccc1C1(O)NC(=O)c2cnccc21</smiles>

(30) meta $n=11$ (31) meta $n=17$

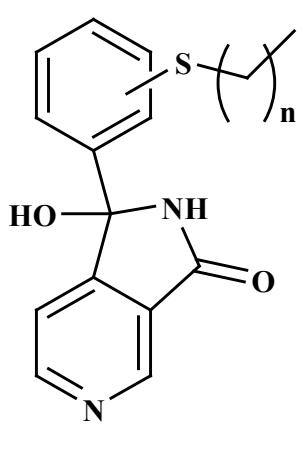

(32) $\mathrm{n}=11$

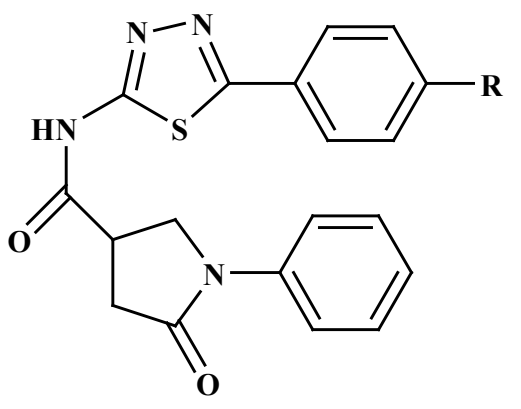

(33) a-e

Fig. 4: Aryl azaisoindolinone InhA inhibitors 
interactions with important amino acid residues of the formerly disordered loop for substrate-binding and NAD cofactor. These results thus provided an insight into the structural requirements for slow onset inhibition of ENR. It also pointed to the fact that PT70 had a significant potential to be effective against sensitive as well as drug-resistant strains of Mycobacterium tuberculosis ${ }^{46}$. Arylamides were found to be associated with high activity in ENR enzyme assay, but low antimycobacterial efficacy. In order to understand the structural activity relationship for improving the antimycobacterial activity, the dynamic behavior analysis of arylamide inhibitors and trans-2-hexadecenoyl-(N-acetylcysteamine)thioester, a substrate was carried out by molecular

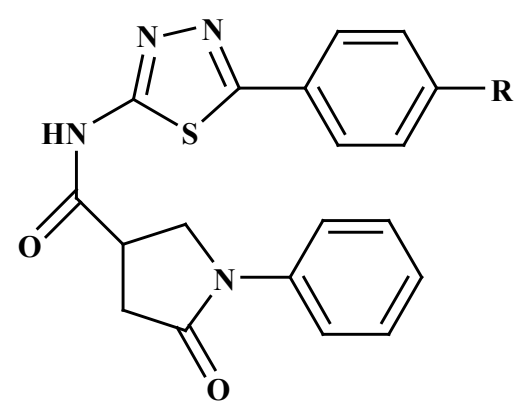

(33) a-e<smiles>CCOc1ccc(-c2nnc(NC(=O)Nc3ccccc3C)s2)cc1</smiles>

(34)<smiles>[R]C(=O)c1ccc(-n2c(C)ccc2C)cc1</smiles><smiles>Cn1[nH]c(=O)c2c(c1=O)CCCC2</smiles>

(39) dynamics (MD) simulation study. Arylamide inhibitors and the substrate were found to be positioned at the same site indicating that they acted as competitive inhibitors. The oxygen of the amide carbonyl was found to confer selectivity for InhA inhibition. Moreover, it was also found that this group was critical for hydrogen bond formation of these arylamides with NADH and Tyr158 of InhA. It was thus realized that aryl ring substitution by hydrophilic groups enhanced the selectivity of these compounds to InhA and incorporation of more lipophilic groups into the substituent $B$ resulted in the increase of their membrane permeability and the correct balance between the membrane permeability and selectivity could be used to improve their inhibition potential against Mycobacterium tuberculosis ${ }^{47}$. Delaine et al., in 2010 reported that shortened adducts of isoniazid-NAD containing a lipophilic fragment could act as effective bi-substrate inhibitors of InhA and antimycobacterial compounds ${ }^{48}$. Such truncated adducts resembling the active metabolite of isoniazid, were designed and synthesized combining a lipophilic hydrocarbon resembling the ENR substrate and the nicotinamide group of NAD. Both classical nucleophilic substitutions and Suzuki-Miyaura cross-coupling reaction were used to introduce the lipophilic fragment. The synthesized compounds were able to show significant inhibition<smiles>[R]c1ccc(/C=N/NC(=O)c2ccc(-n3cccc3)cc2)cc1</smiles><smiles>CN1NC(=O)C2C3C=CC(C3)C2C1=O</smiles>

(37)<smiles>CN1NC(=O)C2CCCCC2C1=O</smiles>

(40) 
of InhA along with promising antimycobacterial activities. Three series based on pyridinium, pyridine, and 1,4-dihydropyridines (Fig. 3) were synthesized that were simplified derivatives of ENR-NAD adduct structurally. More active compounds were formed on introduction of a lipophillic fragment into nitcotinamide hemiamidal framework. Compounds (25), (26), (27), (28) and (29) showed a significant InhA inhibitory activity. Several in silicoQSAR studies were carried out to generate pharmacophore models using different scaffolds for Inh A inhibitors. Furthermore molecular docking analysis was done to explore the interactions of 28 arylamide derivatives with the target enzyme ${ }^{49}$. CoMFA, CoMSIA, and HQSAR studies were employed to determine the structure activity relationship of these arylamide derivatives. It was found out that the critical structural features for the these arylamides to fit into the binding pocket of InhA included $\mathrm{H}$-bond formation between the oxygen of the amide carbonyl and the hydroxyl substituents of Tyr158 and nicotinamide ribose; hydrogen bond-formation between oxygen of pyrophosphate and NADH with ring A meta and ortho hydrogens; appropriate size of ring $A$ and ring $B$ substituents for an optimum distance for hydrogen bond interactions with NADH and Tyr158; hydrophobic ring B interactions with Met232, Ala157, Ile215,Met199, Leu218, Pro193,Val203, Trp222 and Ile202. A pharmacophore model was built taking a conformation of indole-5-amide inhibitor (Genz 10850) bound to InhA using LigandScout (PDB code: IP44) ${ }^{50}$. This model was then applied to forty structurally varied arylcarboxamide analogues synthesized by Kuo et a ${ }^{45}$ to align them in order to identify the bioactive conformation. Based on pharmacophore alignment (CoMFA) and CoMSIA analysis of arylcarboxamides-based inhibitors of InhA and graphical interpretation of the data the information about the critical structural attributes of these arylcarboxamides for inhibition of InhA were obtained. The developed pharmacophore model could thus be applied to discover new hits by virtually screening commercial databases and then calculate the activities. Deraeve C. et al., ${ }^{51}$ designed and<smiles>[R3]NC(=O)Cn1c([R3])nc2ccc([R])cc2c1=O</smiles>

(41)<smiles>O=C(Cn1c(=O)oc2ccccc21)Nc1cc(Cl)ccc1Cl</smiles>

(42)<smiles>[R2]NC(=O)Cn1c(=O)oc2cc([R])ccc21</smiles>

(43)<smiles>[R]c1ccccc1Oc1ccc(C(C)(C)C)cc1O</smiles>

(44) synthesized azaisoindolinone based compounds containing a lipophilic chain as inhibitors of InhA and as anti- tubercular agents. SAR studies were done to establish the appropriate size and position of the lipophilic chain around the azaisoindolinone moiety. It was found that the bioisosteric substitution

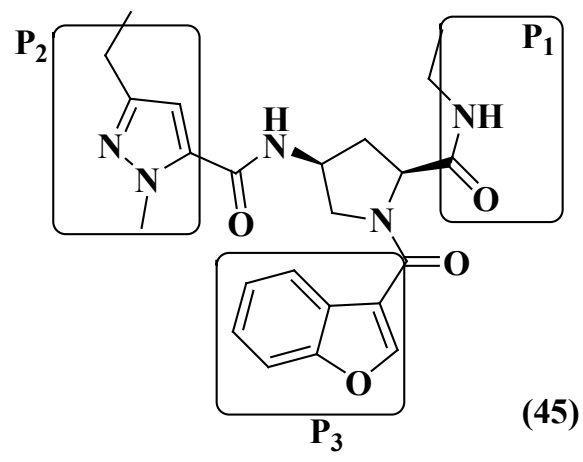<smiles>CCn1nc(C)cc1C(=O)N[C@H]1C[C@@H](C(N)=O)N(C(=O)c2coc3ccccc23)C1</smiles> 
of ether link, the suppression of the phenyl group, and alkylation of the the hemiamidal nitrogen and tertiary hydroxyl affected the inhibition activity. This insightful information could thus be employed for further modification of the azaisoindolinone framework for development of new anti-TB agents.

It was observed that aryl azaisoindolinone framework (fig.4) has a tendency to form epimers at the C-7 carbon by opening of ring. SAR analysis around the parent azaisoindolinone scaffold (30) was performed to help in confirming some pharmacophore elements. It was observed that presence of phenyl ring with lipophilic chain on the azaisoindolinone moiety resulted in the most effective molecular interactions with ENR. Furthermore the presence of sulfur or oxygen atom bound long carbon chain (12 or 18) on the phenyl ring at meta position and a C-7 positioned free tertiary hydroxyl resulted in enhanced interaction with InhA. These structural modifications led to an enhanced inhibition of $M$. tuberculosis growth and also in improving the activity against InhA.Compounds (31) and (32) were found to exhibit better inhibition of InhA and superior activity against M. tuberculosis growth than the parent molecule (30). On the basis of docking studies and oral bioavailability scores using Lipinski's rule evaluation, a series of 5-oxo-1-phenyl-N-(5-substituted phenyl-1,3,4-<smiles>CC(C)(C)CC(C)(C)C(=O)NNC(=O)c1ccncc1</smiles>

(47), $n=3-15$<smiles>[R]c1nnc(-c2ccc(C3C=CC=C3)cc2)o1</smiles>

$R=(48 b)$<smiles>CC(=O)CCC(=O)[AlH2]OCCc1nnc(-n2cccc2C)s1</smiles><smiles>Cc1ccc2ccccc2c1</smiles>

(50 b) $\mathrm{Ar}=$

(50 a) $\mathrm{Ar}=$<smiles>Cc1ccc(F)cc1</smiles><smiles>CCN(CC)C(=O)/C(C#N)=C/c1cc(O)c(O)c([N+](=O)[O-])c1</smiles>

(51)<smiles>CN1CCN(C(=O)/C(C#N)=C/c2cc(O)c(O)c([N+](=O)[O-])c2)CC1</smiles><smiles>N#C/C(=C\c1cc(O)c(O)c([N+](=O)[O-])c1)C(=O)NCCCO</smiles><smiles>CC=C[N+](=O)[O-]</smiles>

(51d)<smiles>CN1CCN(C(=O)/C=C/c2cc(O)c(O)c([N+](=O)[O-])c2)C(C#N)C1</smiles><smiles>CSCc1ccc(Cl)cc1</smiles> 
thiadiazol-2-yl)pyrrolidine-3-carboxamides (33a-e) were designed and synthesized as mycobacterium tuberculosis ENR (InhA) inhibitors. They dispalyed good anti tubercular activity confirming them to be promising candidates as Mtb InhA inhibitors ${ }^{52}$. QSAR study was carried out on a twenty member series of 1,4- dihydropyridine derivatives reported as inhA inhibitors to provide reliable clues for further optimization of 1,4-dihydropyridine pharmacophore as effective antitubercular agents by Deshmane $\mathrm{S}$ et al., ${ }^{53}$. An anti-tubercular screening model of pyrrole derivatives was constructed by Zhou, $\mathrm{S}$ et al., ${ }^{54}$ by molecular docking with InhA. An ensemble-docking process employing the Autodock Vina software was carried out by Stigliani JL et al. ${ }^{55}$ with four X-ray crystallographic structures of InhA. Five inhibitors of InhA were docked sequentially in the cavity of the protein for the substrate. Comparison of the calculated conformations to the crystallographic structures was employed to assess and validate the efficiency of the docking. The bioactive conformation of each ligand was retrieved using interaction energies combined with the multiple receptor conformations approach. QSAR study was performed by Jain A $\mathrm{K}$ et al., ${ }^{56}$ using a data obtained for a series of 23 compounds<smiles>O=C(c1ccccc1)N1CC[NH+](Cc2cccc(Oc3ccccc3)c2)CC1</smiles><smiles>O=C(c1ccccc1F)N1CC[NH+](Cc2cccc(Oc3ccccc3)c2)CC1</smiles>

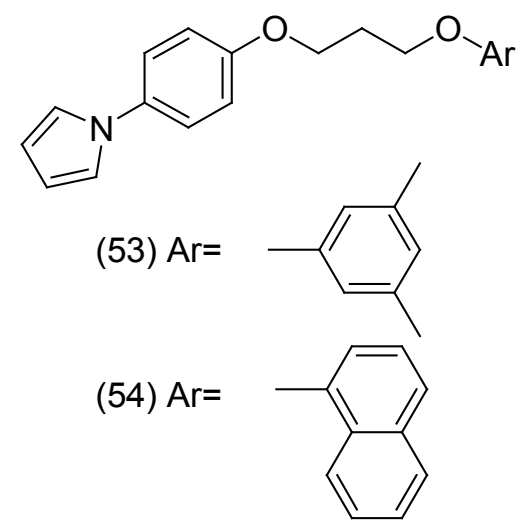

as inhibitors of InhA (Ende et al., 2008) ${ }^{57}$ in order to facilitate the design ofdiaryl ether analogues as ENR inhibitors by making modifications in the B-ring. The information obtained from a study carried out by Kumar V et al. ${ }^{57}$ that direct inhA inhibitors upon binding cause conformational changes in the binding loop for the substrate (SBL) of InhA, could be utilized as a parameter for enhanced binding interaction with InhA. Based on 36 available Mt InhA crystal structures a model of a 3-D pharmacophore was built by Pauli I et al. ${ }^{58}$. So as to identify novel InhA inhibitors from the ZINC database by selecting a library of molecules, the authors employed two different approaches of in silico ligand-screening. 3-D pharmacophore model was first developed using 36 available Mycobacterium InhA crystal structures. Four pharmacophoric points were employed by combining ligand-based and structure-based data in order to get molecules which could compliment the binding features of Mycobacterium InhA substratebinding cavity. To study the binding mode and affinity of the chosen molecules another approach involving the useof four well known docking programs which employ different search algorithms was made.After analyzing the results, out of the six ligands selected<smiles>[R4]NC(=O)[C@H]1C[C@H](NC(=O)c2cc([R4])nn2[R3])CN1C(=O)c1c([R])[X]c2ccccc12</smiles>

for in vitro analysis three molecules were found to exhibit inhibition with $\mathrm{IC}_{50}$ values in the range of 24 $( \pm 2) \mu \mathrm{M}$ to $83( \pm 5) \mu \mathrm{M}$. The most potent compound (34)m displayed an uncompetitive inhibition mode to 2-trans-dodecenoyl-CoA substrates and NADH with $\mathrm{Ki}$ values of $20( \pm 2) \mathrm{i} \mathrm{M}$ and $24( \pm 3) \mu \mathrm{M}$ respectively. A study conducted by Kumar U C et al. ${ }^{59}$ led to generation of a quantitative pharmacophore model by making use of known ENR inhibitors, which was further authenticated by employing a large test set of compounds. 400,000 compounds from a database were screened using the validated pharmacophore model and 25,000 hits were retrieved. Rapid overlay 
of structures (OpenEyertm) with potent ENR inhibitors was employed to grade these hits based on shape and other feature similarity, followed by subjecting them to docking. This led to selection of thirty compounds with greater than eight chemotypes. The compounds were procured commercially and evalvated for inhibition of InhA. Twenty eight out of the selected thirty two compounds at a concentration of $10 \mathrm{mM}$ were found to demonstrate $10-38 \%$ inhibition against InhA. Srinivas et al., reported synthesis of a series of 4-(4-pyrrol-1-yl/2,5-dimethyl4-pyrrol-1-yl) benzoic acid hydrazide derivatives, derived oxadiazoles and azines. Docking of these molecules into InhA revealed binding conformation of these molecules and the vital interactions with the target. It was observed that the compounds (35),
(36), (37), (38), (39) and (40) interacted with InhA enzyme more efficiently ${ }^{60}$

\section{Design and synthesis of a series of twenty} eight 2-(4-oxoquinazolin-3(4H)-yl)acetamide analogues as significant MTB InhA inhibitors has been reported ${ }^{61}$. Compound (41) $\left(\mathrm{R}_{1}=\mathrm{Cl}, \mathrm{R}_{2}=\right.$ Phenyl $\mathrm{R}_{3}=\mathrm{CH}_{3}$ ) was found to be the most potent derivative showing $88.12 \%$ inhibition of ENR at $10 \mathrm{mM}$ and an $\mathrm{IC}_{50}$ of $3.12 \mathrm{mM}$. Furthermore, compound (41) was also found to inhibit drug sensitive $M$. tuberculosis exhibiting an MIC of $4.76 \mathrm{mM}$ and did not show any cytotoxicity at $100 \mathrm{mM}$. Based on earlier reported lead (42) against the MTB InhA a series of twenty seven substituted 2-(2-oxobenzo[d]oxazol-3(2H)-yl) acetamide analogues were synthesized. 2-(6-nitro-
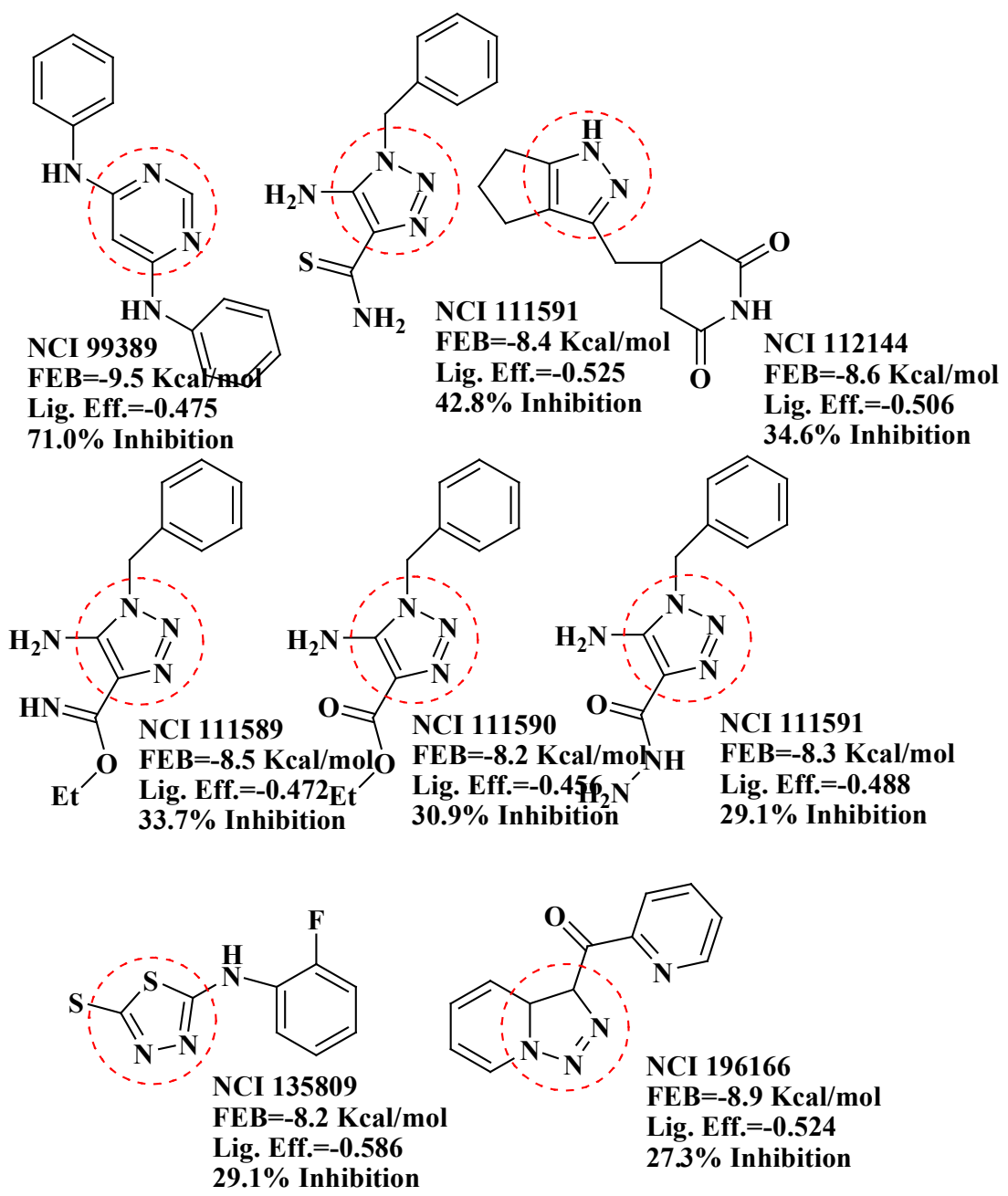

Fig. 6: in-silico docking scores, structures and inhibition of the eight novel inhibitors against InhA 
2-oxobenzo[d]oxazol-3(2H)-yl)-N-(5-nitrothiazol-2-yl) acetamide (43) $\left(R_{1}=\right.$ Nitro, $R_{2}=5$-Nitrothiazol-2-yl) exhibited the most potent inhibiton showing an $\mathrm{IC}_{50}$ of $5.12 \pm 0.44 \mu \mathrm{M}$ against $M$. tuberculosis ENR. It was reported to inhibit the drug sensitive M. tuberculosis with an MIC of $17.11 \mu \mathrm{M}$ and did not show any-cytotoxicity at $100 \mu \mathrm{M}^{62}$. 3D-QSAR analysis and a molecular dynamics simulations study was used to elucidate the underlying structural requirements of diphenyl ether derivatives for inhibition of InhA. 3D-QSAR CoMSIA models were also employed to identify the structural basis for the inhibition based on available experimental binding data of di-Ph ethers. For the calculation of binding free energies four representative compounds were selected and employed for MD simulations with InhA. Obtained results showed that the presence of $\mathrm{R}_{1}$ bulky groups on the $\mathrm{Ph} A$ ring of the molecules would fit well in the hydrophobic pocket formed by residues Met155,Phe149, Ala157,Pro156, Tyr158, Pro193, Val203,Met199, Ile215,Leu207 and Leu218. Furthermore the presence of small hydrophilic substituents at the $R_{3}$ and $R_{4}$ positions of the $\mathrm{Ph} \mathrm{B}$ rings would result in hydrogen bonds interactions with Gly96 and Met98 residues, resp. At $R_{2}$ position the presence of small groups with simultaneous hydrophobic or hydrophilic properties are required toform a favorable interaction with the Me side chain of Ala198 and the pyrophosphate moiety of $\mathrm{NAD}^{+}$, resp. This data helped in the further design of novel and more potent di-Ph ether-based inhibitors against $m t \operatorname{lnh} A^{63,64}$.The study carried out by Pan Pan et al., ${ }^{65,66}$ demonstrated that B-ring modified diaryl ethers (44 a) $\left(\mathrm{R}=\mathrm{CH}_{3}\right)$ and (44 b) $(\mathrm{R}=\mathrm{Cl})$ \} showed time-dependent InhA inhibition and possessed antibacterial activity when administered intraperitoneally, against TB infection in a murine model. The study proposed that residence time of these compounds on the enzyme was related to their efficacy. Based on the diaryl ether scaffold twenty compounds were synthesized, with anA-ring which was hexyl substituted and with several alterations in the B-ring. Following which the synthesized compounds were screened for InhA enzyme inhibition and antibacterial activity using acell based platform. Furthermore crystallographic analysis demonstrated that the slow-binding inhibitors (44c) $(\mathrm{R}=\mathrm{Br})$ and $(44 \mathrm{~d})(\mathrm{R}=\mathrm{CN})$ resulted in a more controlled and closed ENR substrate binding loop. It was also observed that on the B-ringthe bulk of ortho substituents highly influenced the activity of the diaryl ether derivatives. The activity was significantly reduced if greater than two heavy atoms where present in the group. For this group the presence of non-hydrogen bonding donor groups conferred better activity within the suitable size limits. On insertion of substituents on both ortho positions aloss of activity was observed due to a conformation which according to the docking studies, resulted in uncomplimentary van der Waals interactions with InhA. Compound (45) having good inhibition potential but low antitubercular activity was developed by using encoded library technology (ELT) for the discovery of direct InhA inhibitors ${ }^{67}$. With an objective of improving the potency, the proline core was used as template and was systematically investigated by making sequential modifications on the three possible positions to generate chemical diversity. This approach was quickly able to afford structure activity relationship information. Subsequent to optimizing combinations of the most suitable structural features at each position, P3 turned out to be the least complaint positionfor structural activity relationship manipulations. It was found that for potent enzymatic activity,the substituent group at position P3 played a key role. Diethylpyrazole transpired as the most suitable substituent at position P2 for potent antitubercular activity. Ability to improve physicochemical and ADME properties was provided by the SAR analysis around $\mathrm{P} 1$. The optimized lead compound (46) was synthesized by the combination of best structural features. $\mathrm{N}$-acylated isonicotinic acid hydrazide analogues (47) were synthesized ${ }^{68}$ as potential InhA inhibitors and were found to inhibit the growth of Mycobacterium tuberculosis H37Rv and two human clinical isolates of mycobacterium. As compared with isoniazid the synthesized hydrazide derivatives exhibited fair to excellent inhibition against the tested strains and were found to be nontoxic with $L D_{50}$ values ranging from 3898 to 5000 $\mathrm{mg} / \mathrm{kg}$ body wt.Pyrrolyl oxadiazole derivatives[69] were synthesized followed by their molecular modeling and antitubercular evaluation. The result indicated that, the synthesized compounds exhibited moderate antitubercular activity. In docking analysis it was observed that compounds (48a) and (48b) bound tightly to the Enoyl ACP-reductase enzyme. Fifty two, novel pyrrole hydrazine derivatives ${ }^{70}$ were synthesized and screened against the target enoylACP reductase. Surflex-docking method was used 
to explore the binding mode of the synthesized compounds at the active site of InhA. The binding model suggested formation of one or two hydrogen bonds between the InhA and pyrrole hydrazones. The most potent compound (49) (MIC $0.2 \mathrm{mg} / \mathrm{mL}$ ) was found to exhibit $\mathrm{H}$ - bonding interactions similar to that of Triclosan, i.e., with Tyr158 and NADP. Sixty eight novel pyrrolyl substituted aryloxy-1,3,4-thiadiazoles have been synthesized by three-step optimization processes $^{71}$. For pyrrolyl substituted aryloxy-1,3,4thiadiazole series of InhA inhibitors 3D-QSAR was established using the comparative molecular field analysis (CoMFA) and docking studies were also carried out using the crystal structure of InhA. 3D contour plots on analysis helped to explore the effect of different substituents at different positions of the common scaffold. Results obtained through in silico methods were substantiated in invitro testing of ligands using biological assays. Among the compounds investigated, (50a) and (50b) displayed significant activities (3.125 and $6.25 \mu \mathrm{g} /$ $\mathrm{mL}$ ) against $M$. tuberculosis H37Rv strain. Docking simulation studies revealed that these thiadiazoles were mainlybound to the substrate binding site of enoyl reductase and the scoring function for all the derivatives was similar or higher than that of the standard inhibitor. Designed structures have shown interactions with the substrate binding site of InhA, confirming their high inhibitory potency, depending on the type of aryl ring modification. Drug repositioning approach to drug discovery and development was applied in finding potential inhibitors of enoyl reductase ${ }^{72}$.

Entacapone (51), a drug for Parkinson's disease, was also found to inhibit InhA enzyme.
A compd. database was scoured to search for entacapone-like structures, which were then filtered based on LibDock scores. The hits were subsequently docked into InhA binding site by the use of $C$ Docker protocol and their binding energies were calculated. The results showed that the dimer, and an alcoholic and piperazine derivatives of entacapone are potential inhibitors of InhA. H bonding and $p-p$ interactions with nicotinamide adenine dinucleotide (NAD) at the binding pocket were found to be the salient features in binding interactions. The four entacapone analogs (51a-d) exhibited greater binding affinity with InhA compared to entacapone itself (fig. 5). Benzofuran pyrrolidin pyrazole derivatives ( $\mathrm{N}-((3 \mathrm{R}, 5 \mathrm{~S})$-1-(benzofuran-3carbonyl)-5-carbamoylpyrrolidin-3-yl)-1 H-pyrazole5-carboxamide derivatives (52) were reported as direct and strong inhibitors of InhA. With the purpose of investigating the basis for the potency of these compounds against InhA and tuberculosis with respect to their structure, comparative molecular similarity indices analysis (COMSIA) and comparative molecular field analysis (CoMFA) was carried out using $\mathrm{IC}_{50}$ and $\mathrm{MIC}_{90}$ values of a set of thirty four pyrazole, pyrrolidine and benzofuran derivatives. In order to attain favorable $\mathrm{IC}_{50}$ values the core structural motif of the compound used as template was found to be crucial, whereas the $R_{2}$ substituent was found to play a key role in enhancing $\mathrm{MIC}_{90}$ values without negative effects on $\mathrm{IC}_{50}$ values $^{73}$. A novel series of diphenyl ether analogues was synthesized on the basis of matched molecular pair (MMP) method ${ }^{74}$, following which in silico screening was employed to calculate the binding energies of these analogues. Ten unique candidate compounds were identified.They were then evaluated formt<smiles>CC1(C)CCC(Cc2cc(O)c(-c3ccccc3)c(=O)[nH]2)CC1</smiles><smiles>Cc1cccc(Nc2nnc(C(C)(O)c3nc(C)cs3)s2)n1</smiles><smiles>Cc1csc(C(C)(O)c2nnc(Nc3cccc(Br)n3)s2)n1</smiles>

(57)<smiles>Cc1csc(C(C)(O)c2nnc(Nc3cccc(C(F)(F)F)n3)s2)n1</smiles>

(58)<smiles>Cc1csc(C(C)(O)c2nnc(Nc3ccc(Br)cn3)s2)n1</smiles> 
InhA inhibition followed by assessment of their in vitro antibiotic activity against mycobacteria. Their toxicity level on both mammalian cells and intestinal bacteria was also determined. Compound (52d) with phenyl group substitution and compound $(52 \mathrm{~g})$ with 2-fluorobenzyl group as substituents were found to show better inhibition of $m$ tInhA in comparison to the compounds which have a furyl group as terminal substituent.Compound $(52 \mathrm{~g})$ was found to show a relatively lower inhibition of the growth of the mycobacteria. In an effort to develop more potent Inh A inhibitors a series of pyrrolyl phenoxy analogues bearing alkoxy group as linker were prepared and assessed against Mycobacterium tuberculosisfor anti-tubercular property ${ }^{75}$. The optimized pharmacophore model was developed and validated. Compound (53) showed hydrogen bond interactions with Thr196, Met199, Tyr158, and NAD+ that fitted closely into the binding site of $\operatorname{Inh} A$ where as compound (54) was found to show the $\mathrm{H}$-bond with $\mathrm{NAD}^{+}$. Acceptor groups with benzene ring and the alkoxy linker bridge were found advantageous for anti-tubercular activity. Using phenotypic highthroughput whole-cell screening 4-hydroxy-2pyridones have been reported to constitute a new class of direct InhA inhibitors ${ }^{76}$. These compounds were found to show potent bactericidal activity against common isoniazid-resistant TB clinical isolates. It was revealed in biophysical studies that these compounds bound specifically to InhA in an NADH (reduced form of NAD)-dependent manner and blocked the InhA binding. The lead compound NITD-916 (55) directly inhibited InhA dose-dependently. It was also found to show efficacy in in vivo acute and established mouse models of Mycobacterium tuberculosis infection. Virtual screening of compounds from GO FAM project of $\mathrm{NCl}$ was performed against InhA in order to discover new scaffolds for further development The structural features namely, requirement ofcompounds to have an anticipated free binding energy d'"' $8.0 \mathrm{kcal} / \mathrm{mol}$; to form a minimum of two $\mathrm{H}$ bonds with the active site and to base-stack with NAD cofactor were used as interaction-based filters. Eight of the 16 soluble compounds did not involve activation by KatG and exhibited modest inhibition of $(27-71 \%$ at 100 $\mu \mathrm{M})^{77}$. The two best inhibitors that were discovered showed $\mathrm{K}_{\mathrm{i}}$ values of 54 and $59 \mathrm{mM}$, respectively and were fragment-sized analogues (fig.6).Novel inhibitors discovered in this study had very little similarity to known inhibitors of InhA structurally and thus has led to expansion in the diversity of chemical spacefor future exploration. Tetracyclic thiadiazole ${ }^{78}$ based direct and competitive inhibitors of InhA were taken up for further exploration as they were found to have anti-tubercular activity in vivoin murine models. On the basis of this template shortened analogues with three aromatic rings were explored. The analogues (56), (57), (58), (59) and (60) were found to not only exhibit nanomolar InhA potency and anti-mycobacterial activity with submicromolar potency but they also exhibited better physicochemical properties as compared with the tetracyclic thiadiazoles. Compound, (57) was reported as the most potent molecule, while as the pure S-enatiomer of (57) showed significant in vivo efficacy.

\section{CONCLUSION}

The data presented here, firmly reiterates that the pathway for fatty acids biosynthesis is an important target for discovery of drugs for tuberculosis. Given the continuing and developing problems of drug resistance, and in particular multidrug-resistance (MDR), aggressive efforts are required for development of newanti-tubercular drugs in order to combat the bacteria that are resistant to current therapeutics. Several approaches such as de novo design, computational simulation and side activity optimization selectively have been employed for development of inhibitors of FAbl showing good potency, but despite that very few molecules have attained clinical development. More efforts need to be concentrated in enhancing the in vivo properties of the molecules, especially the properties which affect ADME, and other important parameters which influence their potency for development of more efficient InhA inhibitors. 


\section{REFERENCES}

1. Babu, Giridhara R.; Laxminarayan, R. Tuberculosis 2012, 92 (4), 301-306.

2. World Health Organization. WHO progress report20112011.

3. Kaur, R.; Kaur, H. Oriental Journal of Chemistry 2015, 31 (1), 597-600.

4. Billones, J. B.; Carrillo, M.C.O.; Voltaire G. O.; Stephani, J. Y. Macalino, I. A. E.;Bernadette A. S. J.; Oriental Journal of Chemistry 2014, 29(4), 1457-1468..

5. Takayama, K.; Wang,L.; Hugo, L. D.;Antimicrobial agents and chemotherapy 1972, 2 (1), 29-35.

6. Banerjee, A.; Eugenie, D.; Annaik, Q.; Balasubramanian, V.; Kyung, S. U.Science 1994, 263 (5144), 227-230.

7. Annaiek, Q.; Sacchettini, J.C.; Dessen,A.; Vilcheze, C.; Bittman, R.; Jacobs, W. R. ; Blanchard,J. S;Biochemistry 1995, 34 (26), 8235-8241.

8. Sheldon, M.; Bai, G.H.; Suffys, P.; Gomez,L. P.; Fairchok, M.;Rouse, D.;Journal of Infectious Diseases 1995, 171 (4), 954-960.

9. Musser, J. M.; Kapur, V., Williams, D. L.; Kreiswirth, B.N.; Soolingen, D. V.; Embden, .D.V.; Journal of infectious Diseases 1996, $173(1), 196-202$.

10. Zhang, Y.; Heym, B.; Allen, B.; Young, D.; Cole, S. Nature1992, 358(6387), 591-593.

11. Davies, A. P.; Billington,O. J.; Bannister, B. A.; Weir, W. R. C.; McHugh, T. D.; Gillespie, S. H.; Journal of Infection 2000, 41 (2), 184187.

12. Khisimuzi,M.; Slayden, R.A.; Zhu, Y.Q.; Ramaswamy, S.; Pan, X.; Mead, D.; Crane, D.D; Musser, J. M.; Barry, E. A. Science 1998, 280 (5369), 1607-1610.

13. Slayden, R.A.; Richard, E. L.; Barry, C. E. Molecular microbiology 2000, 38 (3), 514525.

14. Larsen, M. H.; Vilchèze, C.; Kremer, L.;Besra, G. S.; Parsons, L.; Salfinger, M.; Heifets, L; Hazbon, M. H.; Alland, D.; Sacchettini, J.C.; Jacobs, W. R .Jr. Molecular microbiology 2002, 46 (2), 453-466.

15. Kremer,L.; Dover, L.G.; Morbidoni, H.R.; Vilchèze, C.; Maughan, W. N.; Baulard, A.; Tu, S.C.;Honore, N.; Derectic V., Sacchettini,
J .C.; Locht, C.; Jacobs, W. R .Jr. ; Besra G.S. Journal of Biological Chemistry 2003, 278 (23), 20547-20554.

16. Andrea, D.; Quemard, A.; Blanchard, J. S.; Jacobs, W. R .Jr. ; Sacchettini, J .C. Science 1995, 267 (5204), 1638-1641.

17. Kai, J.; King, D.S.;Schultz, P.G. Journal of the American Chemical Society 1995, 117 (17), 5009-5010.

18. Marcinkeviciene, J. A.; Magliozzo, R. S.; Blanchard, J. S.Journal of Biological Chemistry1995, 270 (38), 22290-22295.

19. Basso, L. A.; Zheng, R.;Blanchard, .S. Journal of the American Chemical Society1996, 118(45), 11301-11302.

20. Annaik, Q.; Dessen, A.; Sugantino, M.; Jacobs, W. R.; Sacchettini, J. C.; Blanchard, J. S. Journal of the American Chemical Society 1996, 118 (6),1561-1562.

21. Rozwarski, D. A.; Grant, G.A.; Barton, D. H. R.; Jacobs, W. R.;Sacchettini, J. C. Science 1998279 (5347), 98-102.

22. Richa, R.;Whitty, A.; Tonge, P.J. Proceedings of the National Academy of Sciences 2003, 100 (24), 13881-13886.

23. Hao, L.; Tonge, P. Accounts of chemical research 2008, 41 (1), 11-20.

24. Stoeckle, M. Y.; Guan, L.; Riegler, N.; Weitzman, I.; Kreiswirth, B.; Kornblum, J.; Laraque, F.; Riley, L. W. “ Journal of Infectious Diseases 1993, 168 (4) , 1063-1065.

25. Ramaswamy, S.V.; Robert Reich, R.; Dou, S. J.; Jasperse, L.; Pan, X.; Wanger, A.; Quitugua, T.; Graviss, E.A. Antimicrobial agents and chemotherapy 2003, 47 (4), 12411250.

26. Hao, L.; England, K.; Ende, C.A.; Truglio, J. J.; Luckner, S.; Reddy, B.G.; Marlenee, N.L.; Knudsen, S. E.;Knudsen, D. L.; Bowen, R.A.; Kisker, C.; Slayden, R.A.; Tonge, P. ACS chemical biology 2009, 4 (3), 221-231.

27. Lu, X.Y.; Chen, Y. D.; Jiang, Y.J.;You, Q. D. European journal of medicinal chemistry 2009, 44 (9), 3718-3730.

28. Ashutosh, K.;Siddiqi, M. A. Journal of molecular modeling2008, 14(10), 923-935.

29. Kinnings, S. L.; Liu, N.; Buchmeier, N.; Tonge, P.J.; Xie, L.; Bourne, P.E. PLoS Comput 
Biol 2009, 5(7), 1000423.

30. Rao, S.; Vijayakrishnan, G.;R.; Kumar.M.Chemical biology \& drug design 2008, 72 (5), 444-449.

31. Sullivan, T. J.; Truglio, J. J.; Boyne, M.E.; Novichenok, P.; Zhang, X.; Stratton, C. F.; Li, H. J.; Kaur, T.; Amin, A.;Johnson, F.; Slayden, R. A.; Kisker, C.; Tonge. P. ACS chemical biology 2006, 1 (1), 43-53.

32. Kuo, M. R.; Morbidoni, H.R.; Allandll, D.; Sneddon, S. F.; Gourlie, B, B.; Staveski, M. M.; Leonard, M.; Gregory, J. S.; Janjigian, A.D.; Yee, C.; Musser, .M.; Krieswirth, B,; Iwamoto, H.; Perrozo, R.; Jacobs, W.R.; Sacchettini, J.C.; Fidock, D.A. Journal of Biological Chemistry 2003, 278 (23), 20851-20859.

33. Hao, L.;Tonge, P.J.;Current opinion in chemical biology 2010, 14 (4), 467-474.

34. Copeland, R. A., Pompliano, D. L.;Meek, T.M. Nature reviewsDrug discovery2006, 5 (9), 730-739.

35. Tummino, P. J.; Copeland, R.A.; Biochemistry 2008, 47 (20), 5481-5492.

36. Swinney, D. C. Nature reviews Drug discovery 2004, 3 (9), 801-808.

37. Andrew, J.; Sneddon, S. F.; Staveski, M. M., Yee, C.; US6372752 B1 2001, 56.

38. Sylvain, B.; Génisson, V.B.; Gornitzka, H.; Bernadou,.; Meunier, B.;Organic \& biomolecular chemistry 2005, 3 (4), 666669.

39. He, X.; Akram, A.; Stroud, R.; Montellano, P.R.D.O. Journal of medicinal chemistry 2006, 49(21), 6308-6323.

40. He, X.; Akram, A.; Paul, R.Bioorganic \& medicinal chemistry 2007, 15 (21), 66496658.

41. Tonge, P.J.; Sullivan,T.; Johnson, F.; Research Foundation of State University of $N Y$, USA2006, 10.

42. Boyne, M. E.; Sullivan, T..; Lu, H.; Gruppo, V.; Heaslip, D.; Amin, A.G.; Chatterjee, D.; Lenaerts, A.; Tonge, P.J.; Slayden, R.A.. Antimicrobial agents and chemotherapy2007, 51 (10), 3562-3567.

43. Wall, M.D.; Oshin,M.; Chung, G.A.C.; Parkhouse, T.; Gore, A.; Herreros, E.; Cox, B.; Duncan K.; Evans, B.; Everett, M.; Mendoza, M. Bioorganic \& medicinal chemistry letters 2007, 17 (10), 2740-2744.
44. Ende, C.W.A.; Knudson, S. E.; Liu, N.; Childs,J.; Sullivan,T.J.; Boyne,M.; Xu, H.; Gegina, Y.; Knudsen, D.L.; Johnson, F.; Peloquin, C.A.; Slayden, R.A.; Tonge, P.J. Bioorganic \& medicinal chemistry letters 2008, 18 (10), 3029-3033.

45. Freundlich, J. S.; Wang, F.; Vilchèze, C.; Gulten, G.; Langley, R.; Schiehser, G.A.; Jacobus, D. P.; Jacobs, W. R.; Sacchettini..C.; ChemMedChem 2009, 4 (2), 241-248.

46. Luckner, S. R.; Liu, N.; Ende, C.A; Tonge, P.J.;Kisker, C. Journal of Biological Chemistry 2010, 285 (19), 14330-14337.

47. Punkvang, A.; Saparpakorn, P.; Hannongbua, S.; Wolschann, P.; Beyer, A;Pornpan Pungpo, P.; European journal of medicinal chemistry 2010, 45 (12), 5585-5593.

48. Delaine, Tamara, Vania Bernardes-Génisson, Annaïk Quémard, Patricia Constant, Bernard Meunier, and Jean Bernadou. European journal of medicinal chemistry2010, 45 (10), 4554-4561.

49. Auradee, P.; Saparpakorn, P.; Hannongbua, S.; Wolschann, P.; Berner, H.;Pungpo, P.;Monatshefte für Chemie-Chemical Monthly 2010, 141 (9), 1029-1041.

50. Lu, X.Y.; Chen, Y.D.;You, Q.D.; Chemical biology \& drug design 2010,75 (2), 195203.

51. George, S. O. N. I. A.;Kochupappy, R.T.International Journal of Pharmacy and Pharmaceutical Sciences 2013, 3 (4), 280284.

52. Sonali, D.; Asgaonkar, K. D.; Patil, S.; Landge, D.; Chitre, T.S. Inventi Rapid: Med Chem 2012, 208

53. Shanshan, Z.X., Zhenmin,M.Computers and Applied Chemistry2012, 29(4), 427-430.

55. Stigliani, J.L.; Génisson, V.B.; Bernadou, J.; Pratviel, G.Organic \& biomolecular chemistry 2012, 10 (31), 6341-6349.

56. Abhishek, J.K..; Veerasamy, R.; Vaidya, A.; Kashaw, S.;. MouryaV. K.; Agrawal, R. K. Medicinal Chemistry Research 2012, 21 (2), 145-151.

57. Kumar, V.;Sobhia, M.E.;International journal of computational biology and drug design 2013, 6 (4), 318-342.

58. Ivani, P.; Santos, R.N.C.; Rostirolla, D.C.; 
Martinelli, L.K.; Ducati, R. G.; Timmers, L. F.S.M.; Basso, L.A.; Santos, D.S.; Guido, R.V.C.; Andricopula, A.D.; Souza, O.N.D. Journal of chemical information and modeling 2013, 53 (9), 2390-2401.

59. Kumar, U. C., Kumar S.B.V.S.; Mahmood, S.; Sahu, P.K.; Sridevi, J.P.; Ballell, L.; Gomez, D.A.; Malik, S.; Sarma, J.A.R.P. Future medicinal chemistry 2013, 5 (3), 249-259.

60. Shrinivas, J. D.; Uttam A.M.; Pansuriya, K.; Aminabhavi, T. M.; Gadad, A.K.; Journal of Saudi Chemical Society 2013, XXX, XXXXXX

61. Pedgaonkar, G.S.; Sridevi, J.P., Jeankumar, J. U.; Saxena, S.; Devi, P.B.; Renuka, J. ; Yogeeswari, P.;Sriram, D.European journal of medicinal chemistry 2014, 86, 613-627.

62. Pedgaonkar, G.S.; Sridevi, J.P., Jeankumar, J. U.; Saxena, S.; Devi, P.B.; Renuka, J. ; Yogeeswari, P.;Sriram, D. Bioorganic \& medicinal chemistry 2014, 22 (21), 61346145.

63. Kamsari, P.; Koohatammakun, N.; Srisupan, A.; Meewong, P.; Punkvang, A.; Saparpakorn, P.; Hannongbua, S.; Wolschann. P.; Prueksaaroon S, Leartsakulpanich U, Pungpo, P.; SAR and QSAR in Environmental Research 2014, 25(6), 473-488.

64. Kamsari, P.; Punkvang, A.; Hannongbua, S.; Saparpakorn, P.; Pungpo, P.;RSC Advances 2015, 5 (65), 52926-52937.

65. Pan P, Knudson, S. E.; Bommineni, G.R.; Li, H.J., Lai, C.T.; Liu, N.; Diaz, M.G.; Simmerling, C.; Patil, S.S.; Slayden, R. A.; Tonge, P.J. ChemMedChem 2014, 9 (4), 776791.

66. Pan, P.; Liu, N.; Lai, C.T.; Shah, S.; Bommineni, G. R.; Knudson, S.; Slayden, R. A.; Tonge, P.J. In Abstracts Of Papers Of The American Chemical Society, 2011,242, 1155.

67. Lourdes, E.; Keefe, H. O.;Neu, M.; Remuiñán, M. J.; Patel, A. M.; Guardia,A.; Davie, P. D.;Macais, N. P.; Yang, H.; Convey, M. A.; Messer, J.A.; Herran, E.P.; Centrlla, P. A.; Gomez, D.A.; Clark, M.A.; Huss, S.; Donovan, G, K. O.; Muro, F.O.; McDowell, W.; Cataneda, P.; Muendel, C.A.;Pajk, S.; Rullas, J.; Barturen, I.A.; Ruiz, E.A,;Losana, A.M.;Ballell, L, Pichel, J.C.; Evindar, G. J. Med. Chem 2014, 57 (4), 1276-1288.
68. Kumar, H. S. N.; Parumasivam, T.; Ibrahim, P.; Asmawi, M. Z.;Sadikun, A.; Medicinal Chemistry Research 2014, 23 (3), 12671277.

69. Shrinivas, J. D.;Sheshagiri, R. D.; More. U.A.; Rai, S.; Kulkarni, V. H.; Indo American Journal of Pharm Research 2014, 12 (4). 2323-2338

70. More, U. A.; Joshi, S. D.; Aminabhavi, T. M.;Gadad, A. K.; Nadagouda, M. N.; Kulkarni, V.H.; European journal of medicinal chemistry 2014, 71, 199-218.

71. Joshi, S. D.; More, U.A.; Koli, D.; Kulkarni, M. S.; Nadagouda, M. N.; Aminabhavi, T.M.;Bioorganic chemistry 2015, 59, 151167.

72. Cordova, D.L.M.; Abeul, R.J.D.; Galingana, M.O.;Villanueva, L.A.; Billones, J.B.J. Chem. Pharm. Res., 2015, 7(5), 636-642.

73. Pharit, K.; Punkvang, A.; Hannongbua, S.; Saparpakorn, P.; Pungpo. P. RSC Advances 2015, 5(65), 52926-52937.

74. Hironori, K.; Koseki, Y.; Taira, J.; Umei, T.; Komatsu, H.; Sakamoto, H.; Gulten, G.; Sacchettini, J. C.; Kitamura, M.; Aoki, S.European journal of medicinal chemistry 2015,94, 378-385.

75. More, U, A.; Joshi, S. D.; Aminabhavi, T. J; Kulkarni, V. H.; Badiger, A.M.; Lherbet, C.European journal of medicinal chemistry 2015, 94, 317-339.

76. Manjunatha, U. H.; Rao, S. P. S.; Kondreddi, R.R.; Noble, C.G.; Camacho, L.R.; Tan, B.H.; Ng, S.H.; Ng, P.S.; Ma, N. L.; Lakshminarayana, S.B.;Herve, M.; Barnes, S.W.; Yu, W.; Kuhem K.; Blasco, F.; Beer, D.; Walker, J .R.; Tonge, P.J.; Glynne, R.; Smith, P.W.; Diagana. T. T. Science translational medicine 2015, 7(269): 269ra3-269ra3.

77. Perryman, A. L.; Yu, W.; Wang, X.; Ekins, S.; Forli, S.; Li, S. G.; Joel S. Freundlich, J. S.; Tonge, P. J.; Olson, A. J. Journal of chemical information and modeling 201555 (3), 645659.

78. Roman, S.; Sosic, I.; Zivec, M.; Menendez, R. F.; Turk, S.; Pajk, S.; Gomez, D.A.; Triconado, J. R.; Barturen, I. A.;Barros, D.; Pages, L.B.; Young, R..; Encinas, L.; Gobec, S. Journal of medicinal chemistry 2014, 58 (2), 613-624. 